\title{
The Description of Unfair Competition under the Current Legislation of the Russian Federation
}

\author{
Alexander Yurevich Pavlov ${ }^{1}$, Vera Nikolaevna Batova ${ }^{1}$, Alexander Yurevich Sokolov ${ }^{2}$, Natalia Nikolaevna \\ Kovaleva $^{2} \&$ Andrey Vladimirovich Kolesnikov ${ }^{2}$ \\ ${ }^{1}$ Penza State Technological University, Penza, Russian Federation \\ ${ }^{2}$ Saratov State Law Academy, Saratov, Russian Federation \\ Correspondence: Vera Nikolaevna Batova, Penza State Technological University, Prospect Baydukova, Gagarin \\ Street, d.1a/11, Penza, 440039, Russian Federation. E-mail: batova.v.n@yandex.ru
}

Received: November 18, 2014 Accepted: April 7, 2015 Online Published: July 6, 2015

doi:10.5539/ass.v11n21p15 URL: http://dx.doi.org/10.5539/ass.v11n21p15

\begin{abstract}
This scientific paper examines the concept of unfair competition existing in international and Russian law and legal literature. It identifies and explores distinctive characteristics comprising this legal phenomenon. The authors analyzes the types of liability established by the legislation of the Russian Federation for unfair competition in the commodity market. It is administrative, criminal and civil law types of legal liability. The paper examines some of the offenses entailing a public responsibility. The antitrust bodies practice research can help to improve Russian antitrust laws and law of foreign countries.
\end{abstract}

Keywords: unfair competition, responsibility for unfair competition, administrative responsibility, criminal responsibility, civil liability, antitrust laws

\section{Introduction}

Economic competition carries out a number of important regulating functions and ensures development of the market, and therefore has a special government support. Unfair competition is prohibited action, based on dishonest and unfair ways of doing business.

Unfair competition has traditionally been a constant companion of free competition serving as a basic condition for ensuring the harmony of supply and demand on the market of goods and services (Gorodov, 2007, p. 29).

If any areas are not to be regulated by the state, they will be regulated by element, criminals, or oligarchy. This was vividly demonstrated in the Russian economy in the 90-ies of the last century. Now, however, market regulation can be discussed only abstracting from the existing practice, because such regulation is almost impossible to be imagined in a pure form. Market is unable to balance and counterpoise the total demand and supply. It is inclined to monopolize of the spheres of social production. Therefore, the society insures itself by opposing the monopolization of markets by state regulation of their manifestations. (Veselovsky at al., 2015)

\section{Methods and Materials}

When carrying out theoretical and practical research on the state Antimonopoly regulation the authors have used the monographic method. The empirical base of the research and the source of ensuring the conclusiveness of issues and conclusions presented in the work were the official data of The Federal Antimonopoly service, the native and foreign periodical press; the results of researches of scientific centers, the materials of statistical surveys including the results of experts' reports and opinions, the data of reports about the innovative, financial and economic activity of enterprise structures, the materials of the Russian and international scientific and research-to-practice conferences, seminars, "roundtables", the information sources and the Internet.

The regulatory framework of the study is the Constitution of the Russian Federation, antitrust laws and legislative acts providing for administrative, civil and criminal penalties for its violation.

\section{The Main Part}

3.1

The most common definition of unfair competition is codified in Art. 10-bis of the Convention for the Protection of Industrial Property of March 20, 1883 (Convention for the Protection of Industrial Property of 20.03.1883). It 
began to form European legislation aimed to restrict unfair competition. Under this article an act of unfair competition is any act of competition which is in conflict with honest practices in industrial or commercial matters and including all acts capable to create confusion towards the company, products or industrial or trade activities of a competitor, and statements capable to discredit the company and products or industrial or trade activity of a competitor or to put the public across the nature and manufacturing process, the characteristics, the suitability for use or quantity of goods.

Legal doctrine attempted to give the interpretation of the unfair competition definition for many times. G. C. Hins suggested the following definition of unfair competition. It is the use of the right to compete, which is accompanied by ways morally unacceptable, lowering business decency of merchants in relation to each other and discrediting them in the eyes of consumers (Hins, 1931, p. 211). Yu. I. Svyadosts considers unfair competition as doing an action in industrial or commercial matters aimed to gain the benefits through fraud contrary to fair rules or custom of competitors behavior in the capitalist stream of commerce (Svyatosts, 1969, p. 170).

The Russian science worked out various concepts of unfair competition. V. A. Dozortsev considers unfair competition as a provision of a customer (a potential customer) with true or false information which is contrary to usual and customary business practices, requirements of decency, reasonableness and fairness which is able to cause false impression discrediting a competitor, its activities and/or goods (including the ability to cause confusion concerning the nature, manufacturing process, the characteristics, the suitability or quantity of the goods) or to cause confusion with a competitor, his activities and/or his goods (Dozortsev, 1997, p. 33).

Yu. Kasyanov considers unfair competition as competitiveness of independent economic entities in the commodity market targeted to obtain any economic benefits or benefits by generating negative attitude of the consumer towards the products of competitors or generating consumer's attitude towards the goods, which is not in conformity with reality (Kasyanov, 2000, p. 37).

In accordance with the M. G. Dolgikh's definition (Dolgikh, 2003, p. 34), unfair competition is a form of abuse of privilege expressed in wrongful act of market relations subject, which interferes in competitors business rights exercise or harms to consumers by forms of a right exercise contradicting to the law or contrary to usual and customary business practices.

Russian legislature significantly narrowed the unfair competition definition codified in the Convention for the Protection of Industrial Property. Art. 4 of the Federal Law of 26 July 2006 \#135-FZ "On Protection of Competition" (hereinafter - the Law on Protection of Competition), identify unfair competition as any act of economic subjects (group of persons) aimed to receive benefits in business activities contradicting to the laws of the Russian Federation, to usual and customary business practices, to requirements of decency, to reasonableness and fairness and that have caused or will cause damages to other economic entities (competitors) or damaged or will harm their reputation.

\section{2}

The unfair competition definition, which is codified in the Law on Protection of Competition does not provide on-inclusive criterion for accurate determination of an unfair competition act.

Unfair competition is characterized by the following points, which are based on the definition of the Law on Protection of Competition:

1) It is focused to obtain competitive advantages on the relevant commodity market;

This characteristic limits a number of actions, which can be regarded as unfair competition. The actions, which are unprofitable for competitors, cannot be regarded as unfair competition.

2) It contradicts the legislation of the Russian Federation, to usual and customary business practices, requirements of decency, reasonableness and fairness;

This characteristic of unfair competition's contradiction to the legislation of the Russian Federation actually makes illegal and unfair competition similar. Certain incorrect exercise of competition, which do not meet all the criterion of unfair competition, recognized by law, and its bad faith should not be treated as identical concepts.

Under part 1 of Art. 5 of the Civil Code of the Russian Federation dated November 30, 1994 \#51-FZ (hereinafter - Civil Code) the customs of business shall be recognized as the rule of behavior, which has taken shape and is widely applied in a certain sphere of business activities, and which has not been stipulated by legislation, regardless of whether it has or has not been fixed in any document.

3) It damages or can damage other economic entities - competitors; 
Infliction of damages is not essential criterion to establish a fact of unfair competition. Judicial authorities reasonably presume this fact when there is sufficient evidence of causing damages' possibility (The decision of Volga District Arbitrazniy Court of Russian Federation of 01.06.2009 \#A06-6373/2008).

4) It harms or can harm the reputation of other economic entities - competitors.

\section{3}

The Law on Protection of Competition does not provide the concept of "economic entity's business reputation". Analysis of the provisions of the Civil Code and the acts of judicial bodies allows to conclude that business reputation is an intangible benefit (Art. 150 of the Civil Code). It is one of the conditions of its activity representing a set of trustworthy information about this legal entity, goods it produces, performed works, rendered services. Business reputation is of essential value for the productive activities of the organization on the relevant commodity market, which arise in the period of economic activity of the legal entity.

Detailed unfair competition's forms list is contained in the Model Law for Developing Countries "On trademarks, trade names and unfair competition" (The decision of the Supreme Arbitrazniy Court Presidium of Russian Federation of 17.07.2012 \#17 528/11.), elaborated by the World Intellectual Property Organization in 1967:

bribing of competitor's customers with the aim to attract them as clients;

spying or bribery of competitor's employees with the aim to identify industrial or trade secrets;

unauthorized use or disclosure of competitor's know-how;

motivation of competitor's employee to violate or break their contracts with the employer;

threat of competitors by infringement of patents and trademarks suits, if it is done in bad faith and with the purpose to limit competition;

sitting out of another company's trade with the aim to counterstand or prevent competition;

dumping, that is sale of goods on a price lower than it is with the intention to counterstand competition or to suppress it;

creation of impression that customer has an opportunity of purchase on extremely beneficial terms, when in fact it does not so;

intentional imitation of goods, services, advertisement or other aspects of the commercial activities of a competitor;

encouragement of breach of a contract which was concluded by competitors;

production of advertising in which the comparison is made with the goods or services of competitors;

violation of laws which do not regulate competition directly when such a violation allows to achieve unfair advantages over competitors.

\section{4}

The list of actions that constitute the actus reus of this offense is in the art. 14 of the Law, which include:

1) Dissemination of false, inaccurate or falsified information, which may inflict damages to economic entity or damage its reputation;

2) False representation of the nature, method and place of production, usability, quality and quantity of goods or its producers;

3) Economic entity incorrect comparison of produced or sold goods with goods produced or sold by other economic entities;

Incorrect comparison is regarded to be an act of unfair competition in judicial practice, irrespective of whether this information is false (Intellectual property: main materials, 1993. Novosibirsk).

4) Sale, exchange or other introduction into turnover of goods, if there was illegal use of results of intellectual activity and means of individualization equated to them of a legal entity, means of goods, works and services individualization;

At the same time in accordance with Art. 1487 of the Civil Code the use of a trade mark in relation to the goods that were put into circulation in the territory of the Russian Federation by the trademark's holder or with his consent does not stipulate an infringement of the exclusionary trademark rights. 
In this case courts reasonably conclude that the use of means of goods, works and services individualization when goods are put into circulation with the consent of the trademark holder does not set off all elements of unfair competition.

5) illegal receive, use or disclosure of information constituting commercial, official and other protected by law secrets.

Other actions of economic entities can be determined as unfair competition, whether they meet the general concept of unfair competition.

\section{5}

Russian law identifies three types of legal responsibility of economic entities for acts containing elements of unfair competition: administrative, criminal and civil ones.

Generally actions regarded as unfair competition, entail the responsibility under Art. 14.33 of the Code of Administrative Offences of the Russian Federation of December 30, 2001 \# 195-FZ (hereinafter Administrative Code).

Part. 2, Art. 14.33 of Administrative Code provides responsibility for unfair competition that is introduction of goods into circulation with illegal use of results of intellectual activity and equated means of individualization of a legal entity, means of individualization of products, services.

Set of the elements of the offense under Art. 14.33 Administrative Code does not deal with cases of unfair competition in which the law on advertising is violated. Such acts should be determined under Art. 14.3 Administrative Code.

At the same time judicial practice distinguishes actions containing both features of improper advertising and unfair competition.

Creation of a trade name in promotional materials which is confusingly similar to a trade name previously registered by another business entity or to the verbal element of another firm's trademark is an example of such actions (The Law of Russian Federation "Code of Administrative Offences of the Russian Federation" of 30.12.2001).

It appears that if advertisement contrasts some goods with others inflicting damage to business reputation of competitor economic entity, it must be treated as an act of unfair competition under Art. 14.33 Administrative Code.

Several acts of unfair competition entail criminal responsibility.

Thus, the prevention, restriction or elimination of competition by entering of economic entities into agreement restricting competition (cartel), the repeated abuse of a dominant position on establishment and (or) maintaining monopolistically high or low prices of goods, unjustified refusal or evasion of the contract, restricting access to the market, caused large damage to citizens, organizations or state (over 1 million rubles) or resulted high income (over 5 million rubles) are treated as a crime in accordance with Art. 178 of the Criminal Code of the Russian Federation of June 13, 1996 \# 63-FZ (The decision of East-Siberia District Arbitrazniy Court of Russian Federation of 06.04.2009 \#A19-9804/08-35-Ф02-1165/09) (hereinafter - Criminal Code).

Illegal use of a trademark, service mark, appellation of origin or similar designations for homogeneous goods, and illegal use of a trademark, service mark, appellation of origin or similar designations for homogeneous goods, if these acts were committed repeatedly or caused considerable damage exceeded one million five hundred thousand rubles entail criminal responsibility in accordance with Art. 180 of the Criminal Code.

Art. 183 of the Criminal Code criminalize the following cases of illegal acceptance, use, disclosure of information constituting commercial, official or other secrets protected by law: collecting of such information, by stealing of documents, bribery or menace, as well as other unlawful ways; unlawful disclosure or use of such information without consent of the owner by a person to whom it was entrusted or became known at service or work.

Civil liability is the most widespread kind. It arises when economic entity is harmed by the violation of the antimonopoly legislation. Then, in accordance with Part. 3 art. 37 of the Law on Protection of Competition, a person whose rights and interests are violated should bring lawsuits to the court, the Arbitrazniy court under established procedure. A court will restore violated right, compensate damages including loss of expected profit, damages caused to property. 


\section{Conclusion}

Analysis of the antitrust laws allows to state that the absence of a clear legislative definition of unfair competition and actions that are parts of it causes significant problems with enforcement. Thus, it is necessary to improve the protection of economic entities from unfair competition, to formulate the definition of unfair competition, which contains a comprehensive list of its criterion.

\section{Acknowledgments}

The article was written in the framework of State order of the Ministry of education and science of the Russian Federation, project "Inter-disciplinary socio-humanitarian studies in the context of innovative development and world relations" (project code 2232).

\section{References}

Dolgikh, M. G. (2003). Legal nature of unfair competition. Legislation, 11, 34-50.

Dozortsev, V. A. (1997). Unjust or unfair competition? Jurisprudential world, 4, 29-33.

Gorodov, O. A. (2007). The research of unfair competition's notion. News of higher education institute. Jurisprudence, 6, 29-36.

Gorodov, O. A. (2008). Unfair competition: theory and practice (p. 216). Statut.

Hins G. C. (1931). New ideas in the law and main problems of our time (p. 211). Harbin.

Ivanov, I. D. (1980). Modern monopoly and competition (p. 234). Moscow.

Kasyanov, Yu. (2000). Problems of Russian antitrust laws. Legislation and Economy, 6, 25-45.

Svyatosts, Yu. I. (1969). Legal protection of trademarks in the capitalist states (p. 170). Moscow.

Tot'ev, K. Yu. (2003). Competition law (legal regulation of competition and monopolies) (p. 316). Moscow.

Veselovsky, M. Y., Abrashkin, M. S., Aleksakhina, V. G., \& Pogodina, T. V. (2015). Features of State Regulation of the economy in terms of its transition to innovative way of development. Asian Social Science, 11(1), 288-296. http://dx.doi.org/10.5539/ass.v11n1p288

\section{Copyrights}

Copyright for this article is retained by the author(s), with first publication rights granted to the journal.

This is an open-access article distributed under the terms and conditions of the Creative Commons Attribution license (http://creativecommons.org/licenses/by/3.0/). 